\title{
Canadian Orthopaedic Residents Perception of Their Needs in Elbow Surgery Teaching
}

\author{
CSES, Canadian Shoulder and Elbow Society ${ }^{1}$
}

${ }^{1}$ Canadian Orthopedic Association, 4060 St. Catherine Street West, Suite 620, Westmount, QC, Canada, H3Z 2 Z3. Email: cses@canorth.org

Correspondence: Dominique M. Rouleau, Hopital du Sacré-Cœur de Montreal, C2095-5400 Boul. Gouin Ouest, Montreal, Quebec, Canada.

Author contributions

\begin{tabular}{l|c|c|c|c}
\hline Names & Survey design & Evaluation & Analysis & Manuscript \\
\hline $\begin{array}{l}\text { Michael Carroll } \\
\text { carroll_michael@yahoo.com }\end{array}$ & & $\mathrm{X}$ & $\mathrm{X}$ \\
\hline $\begin{array}{l}\text { Darren Drosdovech (London ON) } \\
\text { ddrosdow@ uwo.ca }\end{array}$ & $\mathrm{X}$ & $\mathrm{X}$ & & $\mathrm{X}$ \\
\hline $\begin{array}{l}\text { Kenneth J. Faber (London ON) } \\
\text { kjfaber@uwo.ca }\end{array}$ & $\mathrm{X}$ & & & \\
\hline $\begin{array}{l}\text { Kevin A Hildebrand } \\
\text { hildebrk@ucalgary.ca }\end{array}$ & $\mathrm{X}$ & $\mathrm{X}$ & & $\mathrm{X}$ \\
\hline $\begin{array}{l}\text { Graham King London ON) } \\
\text { graham.king@ sjhc.london.on.ca }\end{array}$ & & $\mathrm{X}$ & & $\mathrm{X}$ \\
\hline $\begin{array}{l}\text { J Pollock (Toronto, ON) } \\
\text { jpollock@toh.ca }\end{array}$ & $\mathrm{X}$ & $\mathrm{X}$ & $\mathrm{X}$ & $\mathrm{X}$ \\
\hline $\begin{array}{l}\text { Dominique M. Rouleau (Montréal, QC) } \\
\text { dominique.rouleau@ umontreal.ca }\end{array}$ & & & & $\mathrm{X}$ \\
\hline $\begin{array}{l}\text { Emilie Sandman (Montréal QC) } \\
\text { sandman.emilie@gmail.com }\end{array}$ & & & \\
\hline
\end{tabular}

\section{Conflicts of Interest and Source of Funding:}

This research did not receive any specific grant from funding agencies in the public, commercial, or not-for-profit sectors. Dominique M Rouleau is a consultant for Bioventus and Wright. The institution (HSCM) of one or more of the authors (DMR, ES) has received funding from: Arthrex, Conmed, Depuy, Linvatec, Smith \& Nephew, Stryker, Synthes, Tornier, Wright, Zimmer.

Received: December 12, 2017

doi:10.11114/jets.v6i3.2859
Accepted: February 6, $2018 \quad$ Online Published: February 22, 2018

URL: https://doi.org/10.11114/jets.v6i3.2859

\begin{abstract}
Introduction: The aim of this paper is to guide training program and review course curriculum planning in elbow disorders. To this end, a nationwide email survey was administered to residents' in orthopaedic surgery training programs.

Material and Methods: The survey had 12 items that examined learning needs in several domains: assessment of acute and chronic elbow disorders, treatment of elbow disorders and the perceived effectiveness of various practical skills simulation sessions. A rank order list of learning needs was created.

Results: Eighty-eight of 351 residents completed the survey (25\%). Ninety percent of respondents thought that a one-day course would be helpful. The majority of residents felt comfortable evaluating acute traumatic elbow disorders. Their level of comfort was lower in treatment of elective disorders, with only $4 \%$ of residents comfortable managing posterior interosseous nerve and 5\% comfortable managing chronic elbow instability. Only $24 \%$ of residents were comfortable treating terrible triad injuries.

Conclusions: Residents reported a need for additional education in elbow surgery; especially for elective disorders. Educational needs were clustered in several areas including surgical approaches, ligament repair, and surgical management of fracture dislocations.
\end{abstract}




\section{Level of evidence: IV}

Keywords: elbow surgery, orthopaedic teaching, resident perception of teaching needs, resident survey, simulation training, national surgery survey

\section{Introduction}

Surgical education is undergoing significant change (Robbins, Bostrom, Craig, \& Sculco, 2010). Medicolegal concerns and work hour restrictions in North America and Europe have reduced and altered trainee contact with patients (Robbins et al., 2010; Baldwin, Namdari, Donegan, Kamath, \& Metha, 2011; Marcus, Vakharia, Kirkman, Murphy, \& Nandi, 2013; Mir, Cannada, Murray, Black, \& Wolf, 2011; Philibert, Friedmann, \&Williams, 2002). Acquiring cognitive and psychomotor competence for the treatment of uncommon disorders has become more challenging. Elbow surgery is an example of an orthopaedic subspecialty discipline that has a variety of uncommon diagnoses that residents rarely encounter during training. This issue may be compounded in training programs lacking faculty with elbow surgery expertise.

Competency Based Medical Education and the Accreditation Council for Graduate Medical Education (ACGME) Milestones Project are intended to formalize curriculum and assessment and improve the efficiency of resident training (Swing, Clyman, Holmboe, \& Williams, 2009). The six ACGME Core Competencies are: patient care; medical knowledge; practice-based learning and improvement; interpersonal and communication skills; professionalism; and systems-based practice. They were developed by expert working groups and focus on the treatment of common conditions. Milestones are clustered around the domains of knowledge, skills and attitudes and are arranged in a framework of increasing complexity that corresponds to post graduate year of training. Interestingly, the treatment of acute elbow trauma is currently the only elbow disorder content in the Milestones project.

Competence by Design (CBD) framework is an initiative undertaken by the Royal College of Physicians and Surgeons of Canada to improve medical training. This method does not measure the time spent in each surgical/medical specialty, but focuses instead on a series of competencies to acquire, and will be implemented across all specialties within the next few years.

Student surveys are a reliable method to identify educational needs in adults as was shown in recent studies on orthopaedic resident self-assessment (Bradley \& Andolsek, 2016). These surveys were found to be reliable because results improved with the number of years of residency and varied with each milestone. Similar validation of self-competency ratings has been done in various other medical fields (Fetters et al., 2017). Residents are known to rate their knowledge and skill level slightly lower than the faculty would, but their auto-evaluation still remains highly correlated to faculty evaluation (Chou, Lockyer, Cole, \& McLaughlin, 2009; Mandel, Goff, \& Lentz, 2005).

The purpose of this study was to administer a nationwide survey to orthopaedic surgery residents to gather knowledge on their perceived learning deficiencies in elbow disorders. The findings of the survey should be useful for training program and review course curriculum development.

Since 2012, a funded Canadian Shoulder Course is organized by Canadian Shoulder and Elbow Surgeons (CSES), formally Joints Canada. The course format promotes the acquisition of knowledge using structured small-group case discussions and the development of psychomotor skills using thematically related surgical simulation sessions (Canadian Shoulder \& Elbow Society [CSES], 2016). Elbow surgery will be introduced as part of the course in 2017. To ensure an efficient educational experience, we used the "Simulation-Based Deliberate Practice" described by Ericsson (2004) as the optimal learning method in performance improvement. This method relies on: motivated learners, well-defined learning objectives, precise measurements of performance, focused and repetitive practice, and real-time feedback. This approach has been shown to be successful not only in the medical field, but also in sports and music (Ericsson, 2004; Ericsson, 2008; Udani, Macario, Nandagopal, Tanaka, \& Tanaka, 2014).

\section{Material and Methods}

This study reports the results of a national survey sent to all Canadian residents in orthopaedic surgery. There were no incentives to complete the survey.

\subsection{Item Generation}

Survey items were initially generated from the Royal College of Surgeons of Canada (www.royalcollege.ca) objectives of training for orthopaedic surgery and subsequently refined by elbow surgeons using a modified Delphi technique. Following item reduction, the survey consisted of 12 items that were clustered in three areas: Assessment of elbow disorders, Treatment of elbow disorders, and Psychomotor skills simulation sessions. (Table 1) 
Table 1. Survey final version

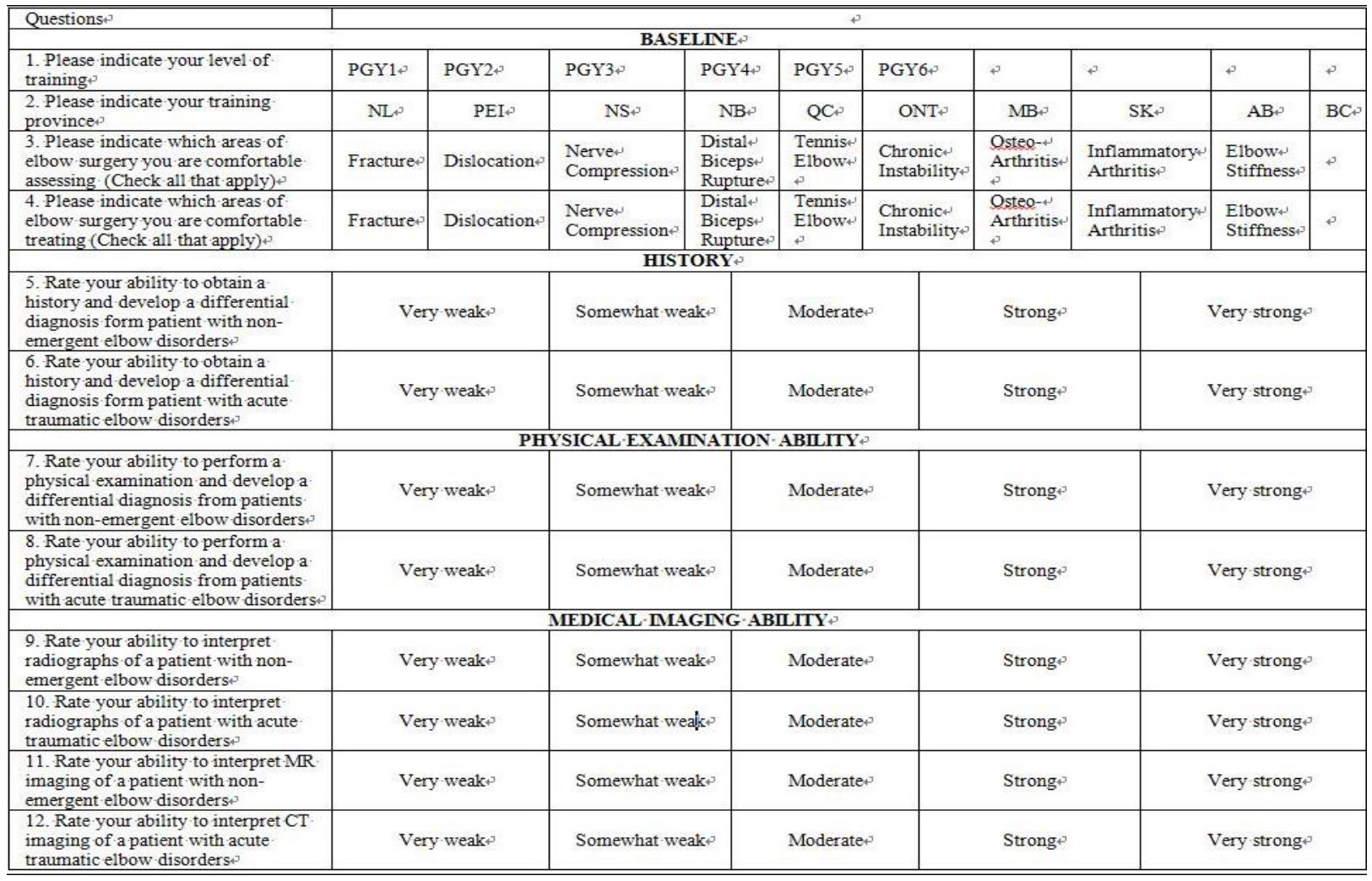

\subsection{Survey Implementation}

The Canadian Orthopaedic Association sent the survey via email to all orthopaedic residents on 3 separate occasions between May $13^{\text {th }} 2015$ and June $16^{\text {th }} 2015$ Canada. During the 2016 June annual meeting of Canadian orthopaedic residents, all the residents present were once again invited to respond.

\subsection{Factual Knowledge About Assessment of Elbow Pathologies}

The first section of the survey focused on the assessment of patients with elbow disorders using binary (yes or no) response questions. (Table 2) The ability to complete a history, perform a physical examination and interpret medical imaging related to acute injuries and elective disorders was queried. The respondents rated their ability to assess various disorders with the following scale: 1-Somewhat weak, 2-Moderate, 3-Strong, 4-Very Strong. (Table 3)

Question: Please indicate which areas of elbow surgery you are comfortable assessing (check all that apply)

Table 2. Assessment of elbow pathologies: Yes or No questions

\begin{tabular}{lcc}
\hline Response & N & \% \\
\hline Chronic instability & 27 & 31.0 \\
Inflammatory arthritis & 33 & 37.9 \\
Elbow stiffness & 45 & 51.7 \\
Nerve compression & 52 & 59.8 \\
Osteoarthritis & 59 & 67.8 \\
Tennis elbow & 67 & 77.0 \\
Dislocation & 79 & 90.8 \\
Distal biceps rupture & 79 & 90.8 \\
Fracture & 85 & 97.7 \\
\hline
\end{tabular}


Table 3. Assessment of elbow pathologies: Ability to administer questionnaire * none of the residents surveyed chose very weak for any of the questions

\begin{tabular}{|c|c|c|c|c|}
\hline Questions & $\begin{array}{l}\text { Some- } \\
\text { What } \\
\text { weak }\end{array}$ & $\begin{array}{l}\text { Mode- } \\
\text { rate }\end{array}$ & Strong & $\begin{array}{l}\text { Very } \\
\text { strong }\end{array}$ \\
\hline $\begin{array}{l}\text { Rate your ability to obtain a history and develop a differential diagnosis from patients with non-emergent elbow } \\
\text { disorders }\end{array}$ & $\begin{array}{c}13 \\
(15.95 \%)\end{array}$ & $\begin{array}{c}39 \\
(47.6 \%)\end{array}$ & $\begin{array}{c}24 \\
(29.3 \%)\end{array}$ & $\begin{array}{c}6 \\
(7.3 \%)\end{array}$ \\
\hline $\begin{array}{l}\text { Rate your ability to obtain a history and develop a differential diagnosis from patients with acute traumatic elbow } \\
\text { disorders }\end{array}$ & $\begin{array}{l}3 \\
(3.7 \%)\end{array}$ & $\begin{array}{c}16 \\
(19.5 \%)\end{array}$ & $\begin{array}{c}48 \\
(58.5 \%)\end{array}$ & $\begin{array}{c}15 \\
(18.3 \%)\end{array}$ \\
\hline $\begin{array}{l}\text { Rate your ability to perform a physical examination and develop a differential diagnosis from patients with } \\
\text { non-emergent elbow disorders }\end{array}$ & $\begin{array}{c}7 \\
(8.9 \%)\end{array}$ & $\begin{array}{c}44 \\
(55.7 \%)\end{array}$ & $\begin{array}{c}26 \\
(32.9 \%)\end{array}$ & $(2.55 \%)$ \\
\hline $\begin{array}{l}\text { Rate your ability to perform a physical examination and develop a differential diagnosis from patients with acute } \\
\text { traumatic elbow disorders }\end{array}$ & $(1.3 \%)$ & $\begin{array}{c}22 \\
(27.8 \%)\end{array}$ & $\begin{array}{c}44 \\
(55.7 \%)\end{array}$ & $\begin{array}{c}12 \\
(15.2 \%)\end{array}$ \\
\hline Rate your ability to interpret radiographs of a patient with non-emergent elbow disorders & $\begin{array}{c}7 \\
(9.0 \%)\end{array}$ & $\begin{array}{c}36 \\
(46.2 \%)\end{array}$ & $\begin{array}{c}30 \\
(38.5 \%)\end{array}$ & $\begin{array}{c}4 \\
(5.1 \%)\end{array}$ \\
\hline Rate your ability to interpret radiographs of a patient with acute traumatic elbow disorders & $\begin{array}{l}3 \\
(3.8 \%)\end{array}$ & $\begin{array}{c}19 \\
(24.4 \%)\end{array}$ & $\begin{array}{c}41 \\
(52.6 \%)\end{array}$ & $\begin{array}{c}15 \\
(19.2 \%)\end{array}$ \\
\hline Rate your ability to interpret MR imaging of a patient with non-emergent elbow disorders & $\begin{array}{c}12 \\
(15.4 \%)\end{array}$ & $\begin{array}{c}35 \\
(44.9 \%)\end{array}$ & $\begin{array}{c}29 \\
(37.2 \%)\end{array}$ & $\begin{array}{c}2 \\
(2.6 \%)\end{array}$ \\
\hline Rate your ability to interpret $\mathrm{CT}$ imaging of a patient with acute traumatic elbow disorders & $\begin{array}{c}7 \\
(9.0 \%)\end{array}$ & $\begin{array}{c}26 \\
(33.3 \%)\end{array}$ & $\begin{array}{c}34 \\
(43.6 \%)\end{array}$ & $\begin{array}{c}11 \\
(14.1 \%)\end{array}$ \\
\hline
\end{tabular}

\subsection{Factual Knowledge About Treatment of Elbow Pathologies}

The second section of the survey focused on the treatment of patients with elbow disorders using binary ("yes or no") response questions. (Table 4) Respondents then rated their level of comfort when treating various disorders using the following scale: 1-Not at all comfortable, 2-Not very comfortable, 3-Neutral, 4-Comfortable, 5-Very Comfortable. (Table 5)

\section{Question: Please indicate which areas of elbow surgery you are comfortable treating (check all that apply)}

Table 4. Treatment of elbow pathologies: Yes or No questions

\begin{tabular}{lrr}
\hline Response & N & \% \\
\hline Chronic instability & 9 & $11.3 \%$ \\
Inflammatory arthritis & 13 & $16.3 \%$ \\
Elbow stifness & 18 & $22.5 \%$ \\
Osteoarthritis & 28 & $35.0 \%$ \\
Nerve compression & 33 & $41.3 \%$ \\
Tennis elbow & 49 & $61.3 \%$ \\
Distal biceps rupture & 55 & $68.8 \%$ \\
Dislocation & 64 & $80.0 \%$ \\
Fracture & 68 & $85.0 \%$
\end{tabular}

Table 5. Treatment of elbow pathologies: Ability to administer questionnaire

\begin{tabular}{|c|c|c|c|c|c|}
\hline Questions & $\begin{array}{l}\text { Not at all } \\
\text { comfortable }\end{array}$ & $\begin{array}{l}\text { Not } \\
\text { comfortable }\end{array}$ & Neutral & Comfortable & $\begin{array}{l}\text { Very } \\
\text { comfortable }\end{array}$ \\
\hline I am comfortable treating distal humerus fracture & $\begin{array}{l}1 \\
(1.3 \%)\end{array}$ & $\begin{array}{l}13 \\
(17.1 \%)\end{array}$ & $\begin{array}{l}27 \\
(35.5 \%)\end{array}$ & $\begin{array}{l}32 \\
(42.1 \%)\end{array}$ & $\begin{array}{l}3 \\
(3.9 \%)\end{array}$ \\
\hline I am comfortable treating terrible triad & $\begin{array}{l}6 \\
(7.9 \%)\end{array}$ & $\begin{array}{l}21 \\
(27.6 \%)\end{array}$ & $\begin{array}{l}29 \\
(38.2 \%)\end{array}$ & $\begin{array}{l}16 \\
(21.1 \%)\end{array}$ & $\begin{array}{c}4 \\
(5.3 \%)\end{array}$ \\
\hline I am comfortable treating olecranon fracture & $\begin{array}{l}1 \\
(1.3 \%)\end{array}$ & $\begin{array}{l}4 \\
(5.3 \%)\end{array}$ & $\begin{array}{l}13 \\
(17.1 \%)\end{array}$ & $\begin{array}{l}29 \\
(38.2 \%)\end{array}$ & $\begin{array}{l}29 \\
(38.2 \%)\end{array}$ \\
\hline I am comfortable treating radial head fracture/dislocation & $\begin{array}{l}2 \\
(2.6 \%)\end{array}$ & $\begin{array}{l}7 \\
(9.2 \%)\end{array}$ & $\begin{array}{l}28 \\
(36.8 \%)\end{array}$ & $\begin{array}{l}31 \\
(40.8 \%)\end{array}$ & $\begin{array}{c}8 \\
(10.5 \%)\end{array}$ \\
\hline I am comfortable treating acute elbow dislocation & $\begin{array}{l}1 \\
(1.3 \%)\end{array}$ & $\begin{array}{c}8 \\
(10.5 \%)\end{array}$ & $\begin{array}{l}20 \\
(26.3 \%)\end{array}$ & $\begin{array}{l}31 \\
(40.8 \%)\end{array}$ & $\begin{array}{l}16 \\
(21.1 \%)\end{array}$ \\
\hline I am comfortable treating chronic elbow instability & $\begin{array}{l}21 \\
(27.6 \%)\end{array}$ & $\begin{array}{l}34 \\
(44.7 \%)\end{array}$ & $\begin{array}{l}17 \\
(22.4 \%)\end{array}$ & $\begin{array}{c}4 \\
(5.3 \%)\end{array}$ & $\begin{array}{l}0 \\
(0.0 \%)\end{array}$ \\
\hline I am comfortable treating ulnar nerve compression & $\begin{array}{c}6 \\
(8.0 \%)\end{array}$ & $\begin{array}{c}17 \\
(22.7 \%)\end{array}$ & $\begin{array}{c}20 \\
(26.7 \%)\end{array}$ & $\begin{array}{c}27 \\
(36.0 \%)\end{array}$ & $\begin{array}{c}5 \\
(6.7 \%)\end{array}$ \\
\hline I am comfortable treating posterior interosseous nerve pathology & $\begin{array}{l}21 \\
(27.6 \%)\end{array}$ & $\begin{array}{l}34 \\
(44.7 \%)\end{array}$ & $\begin{array}{r}18 \\
(23.7 \%)\end{array}$ & $\begin{array}{r}3 \\
(3.9 \%)\end{array}$ & $\begin{array}{r}0 \\
(0.0 \%)\end{array}$ \\
\hline I am comfortable treating elbow contracture & $\begin{array}{l}14 \\
(18.4 \%)\end{array}$ & $\begin{array}{l}37 \\
(48.7 \%)\end{array}$ & $\begin{array}{l}15 \\
(19.7 \%)\end{array}$ & $\begin{array}{c}10 \\
(13.2 \%)\end{array}$ & $\begin{array}{l}0 \\
(0.0 \%)\end{array}$ \\
\hline I am comfortable treating distal biceps rupture & $\begin{array}{l}3 \\
(3.9 \%)\end{array}$ & $\begin{array}{l}16 \\
(21.1 \%)\end{array}$ & $\begin{array}{l}19 \\
(25.0 \%)\end{array}$ & $\begin{array}{l}28 \\
(36.8 \%)\end{array}$ & $\begin{array}{l}10 \\
(13.2 \%)\end{array}$ \\
\hline I am comfortable treating elbow arthritis & $\begin{array}{l}10 \\
(13.3 \%)\end{array}$ & $\begin{array}{l}25 \\
(33.3 \%)\end{array}$ & $\begin{array}{l}23 \\
(30.7 \%)\end{array}$ & $\begin{array}{l}17 \\
(22.7 \%)\end{array}$ & $\begin{array}{l}0 \\
(0.0 \%)\end{array}$ \\
\hline I am comfortable treating elbow osteoarthritis & $\begin{array}{l}12 \\
(15.8 \%)\end{array}$ & $\begin{array}{l}23 \\
(30.3 \%)\end{array}$ & $\begin{array}{l}24 \\
(31.6 \%)\end{array}$ & $\begin{array}{l}17 \\
(22.4 \%)\end{array}$ & $\begin{array}{l}0 \\
(0.0 \%)\end{array}$ \\
\hline I am comfortable treating tennis elbow & $\begin{array}{c}2 \\
(2.6 \%) \\
\end{array}$ & $\begin{array}{c}10 \\
(13.2 \%) \\
\end{array}$ & $\begin{array}{l}26 \\
(34.2 \%) \\
\end{array}$ & $\begin{array}{l}33 \\
(43.4 \%) \\
\end{array}$ & $\begin{array}{l}5 \\
(6.6 \%) \\
\end{array}$ \\
\hline
\end{tabular}




\subsection{Psychomotor Skills Simulation Sessions Relevant for the Resident's Future Practice}

The third section of the survey queried the role of surgical simulation and cadaveric workshops to enhance trainees' ability to treat various elbow disorders. Respondents rated the importance for the following procedures: elbow arthroplasty, elbow arthroscopy, elbow fracture, elbow ligament repair, and surgical approaches. (Table 6)

Table 6. Cadaveric practical session: Grade the importance

\begin{tabular}{|c|c|c|c|c|c|}
\hline Questions & $\begin{array}{l}\text { Not at } \\
\text { all }\end{array}$ & & $\begin{array}{l}\text { Some- } \\
\text { what }\end{array}$ & & $\begin{array}{l}\text { Very } \\
\text { Much } \\
\end{array}$ \\
\hline $\begin{array}{l}\text { A cadaver session on total elbow arthroplasty would be important for my future } \\
\text { practice }\end{array}$ & $\begin{array}{c}8 \\
(10.7 \%)\end{array}$ & $\begin{array}{c}6 \\
(8.0 \%)\end{array}$ & $\begin{array}{c}19 \\
(25.3 \%)\end{array}$ & $\begin{array}{c}18 \\
(24.0 \%)\end{array}$ & $\begin{array}{c}24 \\
(32.0 \%)\end{array}$ \\
\hline A simulation session on elbow arthroscopy would be important for my future practice & $\begin{array}{c}5 \\
(6.7 \%)\end{array}$ & $\begin{array}{c}8 \\
(10.7 \%)\end{array}$ & $\begin{array}{l}17 \\
(22.7 \%)\end{array}$ & $\begin{array}{c}19 \\
(25.3 \%)\end{array}$ & $\begin{array}{c}26 \\
(34.7 \%)\end{array}$ \\
\hline A practical session on elbow fracture would be important for my future practice & $\begin{array}{c}0 \\
(0.0 \%)\end{array}$ & $\begin{array}{c}1 \\
(1.3 \%)\end{array}$ & $\begin{array}{c}2 \\
(2.7 \%)\end{array}$ & $\begin{array}{c}19 \\
(25.3 \%)\end{array}$ & $\begin{array}{c}53 \\
(70.7 \%)\end{array}$ \\
\hline $\begin{array}{l}\text { A practical session on elbow ligament repair and reconstruction would be good for my } \\
\text { future practice }\end{array}$ & $\begin{array}{c}1 \\
(1.3 \%)\end{array}$ & $\begin{array}{c}0 \\
(0.0 \%)\end{array}$ & $\begin{array}{l}5 \\
(6.7 \%)\end{array}$ & $\begin{array}{c}30 \\
(40.0 \%)\end{array}$ & $\begin{array}{c}39 \\
(52.0 \%)\end{array}$ \\
\hline A practical session on elbow surgical approaches would be good for my future practice & $\begin{array}{c}0 \\
(0.0 \%)\end{array}$ & $\begin{array}{c}0 \\
(0.0 \%)\end{array}$ & $\begin{array}{c}2 \\
(2.7 \%)\end{array}$ & $\begin{array}{c}15 \\
(20.0 \%)\end{array}$ & $\begin{array}{c}58 \\
(77.3 \%)\end{array}$ \\
\hline
\end{tabular}

2.6 Data Analysis

Descriptive data was expressed in percentages. The expected duration of the course and the criteria that would influence attendance were evaluated. The residents' needs were divided in three categories: evaluation of elbow pathologies, treatment of elbow pathologies and surgical skills / simulation training. For each category, items were ranked from highest to lowest perceived need.

\section{Results}

Eighty-eight of 351 (25\%) Canadian residents completed the survey. Responses were received from all levels of training with the following distribution: 14 post-graduate year (PGY) 1 (16\%), 17 PGY2 (19\%), 15 PGY3 (17\%), 19 PGY4 (22\%), 22 PGY5 (25\%) and 1 PGY6 (1\%). In terms of geographic distribution: there were 41 residents from Quebec (47\%), 27 from Ontario (31\%), 13 from British-Colombia (15\%), 4 from Alberta (5\%), and 1 each from Newfoundland-Labrador, Manitoba, and Saskatchewan for $1 \%$ each. $91 \%$ of residents were in favour of a 1-day course, $8 \%$ of a half-day course, and $1 \%$ reported no interest, with $75 / 88(85 \%)$ residents completing the full survey. The proportion of responders in each residency year and in each province can be found in tables 7 and 8.

Table 7. Responses by year of training

\begin{tabular}{lccc}
\hline Year of training & Sent survey & Answered survey & \% \\
\hline R1 & 81 & 14 & $17.2 \%$ \\
R2 & 75 & 17 & $22.6 \%$ \\
R3 & 77 & 15 & $19.4 \%$ \\
R4 & 73 & 19 & $26.0 \%$ \\
R5 & 72 & 22 & $30.5 \%$ \\
R6 & 1 & 1 & 100 \\
\hline
\end{tabular}

Table 8 . Responses by province

\subsection{Assessment of Elbow Pathologies}

\begin{tabular}{lccc}
\hline Province & Sent survey & Answered survey & $\%$ \\
\hline Newfoundland & 13 & 1 & $7.6 \%$ \\
Nova Scotia & 21 & 0 & $0 \%$ \\
Quebec & 115 & 41 & $35.6 \%$ \\
Ontario & 129 & 27 & $20.9 \%$ \\
Manitoba & 16 & 1 & $6.2 \%$ \\
Saskatchewan & 14 & 1 & $7.1 \%$ \\
Alberta & 35 & 4 & $11.4 \%$ \\
British Columbia & 26 & 13 & $50.0 \%$ \\
\hline
\end{tabular}

A divergence in responses was observed for the assessment of elective and acute elbow disorders. The ability to perform a focused history was perceived as strong or very strong in 37\% of residents for elective pathologies and in $77 \%$ for traumatic injuries. Similarly, physical examination ability was graded as very strong or strong for $35 \%$ for elective disorders and $71 \%$ for acute traumatic disorders. Finally, the ability to complete a radiological evaluation in elective disorders was of $44 \%$ and $71 \%$ for acute trauma. Most residents were comfortable assessing acute elbow injuries including fractures, dislocations and distal biceps ruptures. (Table 3). 


\subsection{Treatment of Elbow Pathologies}

Once again, a divergence of responses was observed for the treatment of patients with elective and acute elbow disorders. None of the residents felt "very comfortable" treating chronic elbow instability, posterior inter-osseous nerve pathology, elbow contracture, osteoarthritis, and inflammatory arthritis. The only elective diagnosis respondents were "comfortable" or "very comfortable" treating was tennis elbow. The lowest ranking elective disorders were compressive pathologies of the posterior inter-osseous nerve (4\%), and chronic instability (5\%). (Table 5) As in the assessment section, the same three traumatic diagnoses were linked to a higher level of comfort for residents. (Table 4). More than $50 \%$ of residents felt "comfortable" or "very comfortable" treating traumatic disorders with the exception of distal humerus fractures (46\%) and terrible triad injuries (26\%).

\subsection{Psychomotor Skills Simulation Session Relevant for Future Practice}

A cadaveric practical session on total elbow arthroplasty was "important" or "very important" for $56 \%$ of residents. A practical session on elbow trauma and arthroscopy was judged "important" or "very important" for $96 \%$ and $60 \%$ of residents respectively. Ninety-two percent suggested instruction on ligament surgery and $97 \%$ on surgical approaches. (Table 6)

A "comments" section was offered at the end. The cost, location, content, choice of faculty and cadaveric sessions were all mentioned as important factors to decide whether or not to participate. (Table 9)

Table 9. General comments about important factors that would motivate residents to participate

\begin{tabular}{lrr}
\hline Comments & N & \multicolumn{2}{c}{$\%$} \\
\hline Relevence with practice & 1 & $0.1 \%$ \\
Faculty choice & 6 & $6.0 \%$ \\
Timing & 10 & $10.1 \%$ \\
Cadaver/practical session & 10 & $10.1 \%$ \\
Course content & 12 & $12.1 \%$ \\
Cost & 27 & $27.2 \%$ \\
Location & 33 & $33.3 \%$ \\
\hline Total & 99 & \\
\hline
\end{tabular}

\section{Discussion}

The results of this survey highlight some important issues that can guide training program curricula and course design. In general, the residents were uncomfortable assessing and treating elective elbow disorders indicating knowledge gaps in that field.

Except for terrible triad injuries, residents rated their ability to assess and treat traumatic disorders as "strong "or "very strong". Surprisingly, surgical approaches to the elbow were a major concern for $97 \%$ of residents. This discordance between the ability to treat trauma and the surgical approach knowledge is a concern.

Even though trainees rated their assessment and ability to treat elbow trauma as "good", $96 \%$ of residents would like to have simulation sessions on elbow trauma. This highlights a gap between knowledge and confidence in surgical ability, where residents are comfortable verbalizing the treatment algorithm but not necessarily as comfortable physically performing the treatment.

In cases of elbow instability and ligament repair methods, residents expressed their needs from theoretical knowledge to practical psychomotor skills. Chronic instability was rated as the weakest topic of all with only $31 \%$ of residents comfortable in its assessment and only $11 \%$ comfortable in its treatment. This could be caused by the relative infrequency of this type of elbow pathology.

Organizing elbow surgery simulation is a challenging task, especially in smaller programs with fewer fellowship-trained elbow surgeons. By grouping all academic elbow surgeons within the framework of a national course, we can achieve the simulation situation recommended by Ericsson in which: the residents in attendance come for a specific purpose, are engaged, and motivated to learn; simulation stations are designed to link acquisition of knowledge to the performance of a task; the presence of a large number of elbow experts makes it possible to provide immediate feedback (Ericsson, 2004). Utilizing the information from the surgery, simulation stations will be designed according to the learning needs of the residents' tasks (for example, the medial elbow surgical approach). Residents will perform the task under the direct supervision of an elbow surgery specialist and receive immediate feedback. Direct supervision during simulation is essential, as self-assessment for surgical skills is sometimes difficult (Davis, Mazmanian, Fordis, Van Harrison, Thorpe, \& Perrier, 2006). Consequently, this will translate theoretical knowledge to surgical skill acquisition. Simulation training has been shown to be efficient to improve skills in knee surgery and is now mandatory in training programs in the United States (Cannon et al., 2014); another study indicates that residents are asking for more time to practice surgical skills outside the OR (Camp, Martin, Karam, Ryssman, \& Turner, 2016). Meanwhile, program directors are 
recognizing that multimodality training (simulation, courses, OR assistance, video) is key to resident success (Camp et al., 2016). There is also strong agreement between residents and program directors about the need to make simulation surgery a required component of residents training (Karam, Pedowitz, Natividad, Murray, \& Marsh, 2013).

A single day course cannot provide instruction on all elbow related topics; to improve the educational yield, course content should be based upon resident self-assessment of educational needs. The course curriculum should consequently be based on residents' perceived areas of weaknesses, as identified in the self-assessment survey. Gordon et al. have identified a low to moderate accuracy for self-assessment in adult "students" (Buckley et al., 2009; Colthart et al., 2008; Gordon, 1991). However, they also found that a resident can accurately identify his or her knowledge as weak. This was also shown in a study on surgical skills self-assessment, where resident's evaluation of their skills was highly correlated with the faculty assessments (Mandel et al., 2005). A recent Canadian study supports the ability of orthopaedic residents to self-assess their competency in total knee arthroplasty (TKA) (Trajkovski, Veillette, Backstein, Wadey, \& Kraemer, 2012).

One limitation of this study is the low response rate. The response rate may be similar to other studies, however generalizing the results to all Canadian residents is questionable. It is possible that the residents who answered the survey represented a sample of those with a lower perception of their knowledge surrounding the assessment and management of elbow pathology. Despite repeated efforts, we were unable to obtain a large, more representative sample from all provinces. Fortunately, a slightly greater proportion of target audience trainees (29\% of PGY4 and 5) completed the survey. As pointed out by Yarger et al. (2013) to improve response rate, future surveys should be distributed physically in each program, during program meetings, and should be sponsored by each residency program instead of coming from a national organization. Furthermore, it should be noted that not all aspects of elbow pathologies were represented because of the topic selection in consideration of time constraints. Finally, this is a national survey, and administering a similar survey in other countries would identify regional differences in residency training programs.

In conclusion, this survey has identified several resident-perceived deficiencies in the current training program curricula for the assessment and treatment of both elective and traumatic conditions of the elbow. Our data suggests the need to improve residency education in several elbow-related areas: surgical approaches, ligament repair, and fracture-dislocation surgery. Recognizing that hands-on exposure to all topics may be limited in certain programs, we hope to incorporate areas of deficiency into future shoulder and elbow course curriculum.

\section{Acknowledgements}

We would like to thank Trinity from the COA for her help in this survey. Karine Tardif and Julie Fournier from HSCM and Kathleen Beaumont for manuscript preparation.

\section{References}

Baldwin, K., Namdari, S., Donegan, D., Kamath, A. F., \& Mehta, S. (2011). Early effects of resident work-hour restrictions on patient safety: a systematic review and plea for improved studies. J. Bone Joint Surg. Am., Jan 19; 93(2), e5. https://doi.org/10.2106/JBJS.J.00367

Bradley, K. E., \& Andolsek, K. M. (2016). A pilot study of orthopaedic resident self-assessment using a milestones' survey just prior to milestones implementation. Int. J. Med. Educ., Jan 11; 7, 11-18. https://doi.org/10.5116/ijme.5682.6dfd

Buckley, S., Coleman, J., Davison, I., Khan, K. S., Zamora, J., Malick, S., ... Sayers, J. (2009). The educational effects of portfolios on undergraduate student learning: a Best Evidence Medical Education (BEME) systematic review. BEME Guide No. 11. Med Teach., Apr; 31(4), 282-298. https://doi.org/10.1080/01421590902889897

Camp, C. L., Martin, J. R., Karam, M. D., Ryssman, D. B., \& Turner, N. S. (2016). Orthopaedic Surgery Residents and Program Directors Agree on How Time Is Currently Spent in Training and Targets for Improvement. Clin. Orthop. Relat. Res., Apr; 474(4), 915-925. https://doi.org/10.1007/s11999-015-4265-2

Canadian Shoulder and Elbow Society [CSES]. (2016) Design and implementation of the 2012 Canadian shoulder course for senior orthopedic residents. Orthop Traumatol Surg Res., Nov; 102(7), 885-890.

https://doi.org/10.1016/j.otsr.2016.08.013

Cannon, W. D., Garrett, W. E. Jr, Hunter, R. E., Sweeney, H. J., Eckhoff, D. G., Nicandri, G. T. ... Reinig, K. D. (2014). Improving residency training in arthroscopic knee surgery with use of a virtual-reality simulator. A randomized blinded study. J. Bone Joint Surg. Am., Nov 5; 96(21), 1798-1806. https://doi.org/10.2106/JBJS.N.00058

Chou, S., Lockyer, J., Cole, G., \& McLaughlin, K. (2009). Assessing postgraduate trainees in Canada: are we achieving diversity in methods? Med. Teach., Feb; 31(2), e58-63. https://doi.org/10.1080/01421590802512938

Colthart, I., Bagnall, G., Evans, A., Allbutt, H., Haig, A., Illing, J., \& McKinstry, B. (2008). The effectiveness of self-assessment on the identification of learner needs, learner activity, and impact on clinical practice: BEME 
Guide no. 10. Med. Teach., 30(2), 124-145. https://doi.org/10.1080/01421590701881699

Davis, D. A., Mazmanian, P. E., Fordis, M., Van Harrison, R., Thorpe, K. E., \& Perrier, L. (2006). Accuracy of physician self-assessment compared with observed measures of competence: a systematic review. JAMA. Sep 6; 296(9), 1094-102. https://doi.org/10.1001/jama.296.9.1094

Ericsson, K. A. (2008). Deliberate practice and acquisition of expert performance: a general overview. Acad. Emer. Med., 15(11), 988-994. https://doi.org/10.1111/j.1553-2712.2008.00227.x

Ericsson, K. A. (2004). Deliberate practice and the acquisition and maintenance of expert performance in medicine and related domains. Acad Med., Oct; 79(10 Suppl), S70-81. https://doi: 10.1111/j.1553-2712.2008.00227.x/full

Fetters, M. D., Motohara, S., Ivey L., Narumoto, K., Sano, K., Terada, M, ... Inoue, M. (2017). Utility of self-competency ratings during residency training in family medicine education-emerging countries: findings from Japan. Asia Pac. Fam. Med., Jan 10; 16(1). eCollection 2017. https://doi.org/10.1186/s12930-016-0031-1

Gordon, M. J. (1991). A review of the validity and accuracy of self-assessments in health professions training. Acad Med., Dec; 66(12) , 762-769. https://doi.org/10.1097/00001888-199112000-00012

Karam, M.D., Pedowitz, R.A., Natividad, H., Murray, J., \& Marsh, J. L. (2013). Current and future use of surgical skills training laboratories in orthopaedic resident education: a national survey. J. Bone. Joint Surg. Am., Jan 2; 95(1), e4. https://doi.org/10.2106/JBJS.L.00177

Mandel, L. S., Goff, B. A., \& Lentz, G. M. (2005). Self-assessment of resident surgical skills: is it feasible? Am. J. Obstet Gynecol., Nov; 193(5), 1817-1822.

Marcus, H., Vakharia, V., Kirkman, M. A., Murphy, M., \& Nandi, D. (2013). Practice makes perfect? The role of simulation-based deliberate practice and script-based mental rehearsal in the acquisition and maintenance of operative neurosurgical skills. Neurosurgery. Jan; 72(Suppl 1), 124-130.

https://doi.org/10.1227/NEU.0b013e318270d010

Mir, H., Cannada, L. K., Murray, J. N., Black, K. P., \& Wolf, J. M. (2011). Orthopaedic resident and program director opinions of resident duty hours: A national survey. J. Bone Joint Surg. Am., Dec 7; 93(23), e1421-429. https://doi.org/10.2106/JBJS.K.00700

Philibert, I., Friedmann, P., \& Williams, W. T. (2002). ACGME Work Group on Resident Duty Hours. Accreditation Council for Graduate Medical Education. New requirements for resident duty hours. JAMA. Sep. 4; 288(9), $1112-1124$.

Robbins, L., Bostrom, M., Craig, E., \& Sculco, T. P. (2010). Proposals for change in orthopaedic education: recommendations from an orthopaedic residency directors' peer forum. J. Bone Joint Surg. Am., Jan; 92(1), 245-249. https://doi.org/10.2106/JBJS.I.00210

Swing, S. R., Clyman, S. G., Holmboe, E. S., \& Williams R. G. (2009). Advancing Resident Assessment in Graduate Medical Education. J. Grad. Med. Educ., Dec; 1(2), 278-286. https://doi.org/10.4300/JGME-D-09-00010.1

Trajkovski, T., Veillette, C., Backstein, D., Wadey, V. M., \& Kraemer, B. (2012). Resident self-assessment of operative experience in primary total knee and total hip arthroplasty: Is it accurate? Can. J. Surg., Aug; 55(4), S153-157. https://doi: 10.1503/cjs.035510

Udani, A. D., Macario, A., Nandagopal, K., Tanaka, M. A., \& Tanaka, P. P (2014).

Simulation-based mastery learning with deliberate practice improves clinical performance in spinal anesthesia. Anesthesiol Res. Pract., 2014, 659160. https://doi.org/10.1155/2014/659160

Yarger, J. B., James, T. A., Ashikaga, T., Hayanga, A. J., Takyi, V., Lum, Y., Kaiser, H., \& Mammen, J. (2013). Characteristics in response rates for surveys administered to surgery residents. Surgery. Jul; 154(1), 38-45. https://doi.org/10.1016/j.surg.2013.04.060

\section{Copyrights}

Copyright for this article is retained by the author(s), with first publication rights granted to the journal.

This is an open-access article distributed under the terms and conditions of the Creative Commons Attribution license which permits unrestricted use, distribution, and reproduction in any medium, provided the original work is properly cited. 